\title{
Plant Diversity in a Constructed Wetland for Pollutant Parameter Processing on Leachate: A Review
}

\author{
Isni Arliyani ${ }^{*}$, Bieby Voijant Tangahu', Sarwoko Mangkoedihardjo ${ }^{1}$ \\ 1 Department of Environmental Engineering, Institut Teknologi Sepuluh Nopember (ITS), Surabaya, 60111, \\ Indonesia \\ * Corresponding author's email: isni.207014@mhs.its.ac.id
}

\begin{abstract}
The leachate from landfill constitutes high pollutant. The high pollutant content impacts the public and ecosystem health surrounding the landfill site. Therefore, it is essential to process the leachate first before its disposal to water body. Landfill leachate processing can be carried out using three processes, i.e., physical-chemical, biological, and a combination of those. A constructed wetland is currently considered as an environmentally friendly technology to tackle water pollution and leachate. Another advantage of a constructed wetland is the low operational cost and natural maintenance, so it can be a solution related to the cost, technical, and operating system problems of conventional processing. This article aimed to discover the characteristic differences of landfill leachate, constructed wetland installation position, and types of plants used in the constructed wetland. This article was written using the literature reviews from experimental studies on water processing with the same parameter for leachate and leachate processing. The literature review result shows that landfill leachate processing depends on different leachate characteristics. The toxic quality of landfill leachate was found through a toxicity test. Leachate treated by the physical-chemical process contains toxic and non-biodegradable organic substances. Hence, the physical-chemical methods should be applied at the beginning of the process and coupled with the biological method at the end of the process to improve the treatment quality. A constructed wetland with diverse plants was found to be more effective in biomass distribution, less prone to seasonal variations, and had a more diverse microbe population than the constructed wetland with a single plant.
\end{abstract}

Keywords: constructed wetland, leachate, landfill age, installation site, plant diversity, phytotreatment.

\section{INTRODUCTION}

The increase in urban solid waste has become a massive burden on society resulting in the environmental and economic problems, particularly in terms of poor solid waste management (Luo et al., 2020). Ninety-five percent of urban solid waste worldwide is disposed of in landfills (Gao et al., 2014). Landfills provoke several risks, as wastes may release harmful elements into the environment. The leachate from landfill remains a critical problem, because it may pose a threats to land, surface water, and groundwater (Yan et al., 2015). Factors such as area conditions, age, type of waste, and operation of the landfill can vary the content of the landfill (Fang et al., 2017). Countries with tropical climate produce more organic wastes (Idris et al., 2004). The content of organic substance in wastewater is represented by the values of Chemical Oxygen Demand (COD) and Biological Oxygen Demand (BOD). The BOD and COD values are used to determine the degradation rate of landfill leachate (Barlaz et al., 2002; Borglin et al., 2004). The values of BOD/COD leachate ratio in tropical regions are $0.03-0.74$ higher than in other regions. In general, the BOD/ COD ratio values in tropical regions are $\mathrm{BOD}>$ $100 \mathrm{~g} / \mathrm{m}^{3}$ and COD $>500 \mathrm{~g} / \mathrm{m}^{3}$ in landfill leachate. Bakhshoodeh et al., (2020) showed that the content of organic substance in leachate is toxic to microbial activities.

Conventional leachate processing is classified into three major groups, those are 1) chemicalphysical process, 2) biological process, and 3) 
combined biological and physical-chemical processed (Iskander et al., 2018). Physical-chemical leachate processing encompasses coagulationflocculation, adsorption, chemical precipitation, membrane filtration, air stripping, exchange, chemical oxidation/continuous oxidation process, and electrochemical. One of the physical-chemical processing techniques is chemical precipitation carried out for the landfill leachate in Turkey with an efficiency of $50 \%$ and an initial COD value of $4.024 \mathrm{~g} / \mathrm{m}^{3}$ to $2.014 \mathrm{~g} / \mathrm{m}^{3}$. The values of COD and BOD resulting from chemical precipitation are still included in the toxic category. Meanwhile, the physical-chemical process using membrane filter for landfill leachate processing in South Korea generated a BOD/COD ratio value of 0.3 and was included in the non-biodegradable category (Kurniawan et al., 2006). Landfill leachate processing using the adsorption technology with activated carbon had an efficiency of $90 \%$ for the COD parameter and resulted in a COD value of $700 \mathrm{~g} / \mathrm{m}^{3}$, that is still toxic (Mojiri et al., 2013; Renou et al., 2008). Landfill leachate processing using a biological process with activated sludge resulted in an initial COD value of 37.024 $\mathrm{g} / \mathrm{m}^{3}$ with an efficiency of $88 \%$ and produced a COD value of $4.443 \mathrm{mg} / \mathrm{L}$ (Çeçen and Çakıroğlu, 2001; Renou et al., 2008). The COD value classification of landfill leachate processing using activated sludge is still considered toxic. Leachate processing using physical-chemical processes still has the organic substance quality that is toxic to microbes. The quality of leachate that does not damage the environment must be improved through physical-chemical treatment and biological methods (Abbas et al., 2009).

The current applicable popular processing technology for landfill leachate which has low cost, is easy to manage (Miao et al., 2019) and can improve the waste quality is plant utilization on the constructed wetland (Ali et al., 2018; Khan et al., 2009). Constructed wetlands have been developed on a laboratory-scale, a pilot-scale, and a field-scale for landfill leachate processing, with high efficiency in pollutant reduction (Nivala et al., 2007). The constructed wetland is environmentally engineered using various mineral substrates, plants, microorganisms, and retention times that aim to remove biodegradable organics matter, as well as reduce content of metals and pathogens in wastewater (Kadlec and Wallace, 2009; Li et al., 2014). Constructed wetland with plants have a higher pollutant removal efficiency than the ones without vegetation (Zhu et al., 2018). Plant selection should be considered in order to obtain a high efficiency (Zheng et al., 2016). Plants are the primary biological components of $\mathrm{CW}$ that stabilize the surface layer, reduce the content of metals, and encourage microbial growth in the rhizosphere as well as various biological and chemical reactions to detoxify wastewater (Vymazal, 2013). As the primary component, there are many plants that have been utilized in a constructed wetland, such as Phragmites australis, Cyperus papyrus, Canna indica, Scirpus grossus, and Typha latifolia (Nguyen et al., 2020; Sandoval et al., 2019; Shelef et al., 2013; Vymazal, 2013, 2011a). The ability to improve the organic substance toxic quality on landfill leachate using Canna indica and Typha latifolia to be biodegradable with COD values of 136 and $118 \mathrm{~g} / \mathrm{m}^{3}$ (Yalçuk and Ugurlu, 2020). A study by Sharma et al., (2014) used Phragmites australis and Canna indica for landfill processing, where the COD influent obtained was $159.95 \mathrm{~g} / \mathrm{m}^{3}$ and could be processed to reach $81.64 \mathrm{~g} / \mathrm{m}^{3}$. The study could transform the organic substance quality of landfill leachate from biodegradable to stable.

On the basis of these facts, plants are proven to have great and promising potential in improving the quality of organic matter in constructed wetlands through the planting process. Therefore, it is very necessary and crucial to conduct a study that discusses the intensification of plant diversity and construced wetlands in waste management. The aim is none other than to produce quality organic material waste that is biodegradable for microbiological processing.

\section{POTENTIAL OF PLANT DIVERSITY}

\section{Single Plant Utilization}

The plant presence is the most prominent characteristic of constructed wetland that differs it from unplanted lands. Plants are crucial component in the design of constructed wetland. Plants have several properties related to the process in constructed wetland (Brix, 1997). The options for the use of single plants that can be used in this case include Phragmites australis, Juncus effusus, Glyceria maxima, Typha latifolia, Iris pseudacorus (Białowiec et al., 2012), Cyperus papyrus, Phragmites mauritianus, Limnocharis flava, Typha angustifolia, Cyperus haspan, Eichhornia crassipes (Akinbile et al., 2012), Carex rostrata, 
Acorus calamus, Thalia geniculate, Sagittara latifolia, Scirpus lacustris (Belmont et al., 2004; Dallas and Ho, 2005; Moshiri and Brix, 2020; Tanaka et al., 2011) or Canna indica (Liang et al., 2011). The Phragmites australis species, Scirpus species, and Typha species are the plants commonly used in constructed wetlands (Vymazal, 2011a). Plant species in constructed wetlands employed for waste management have been studied extensively; however, the use of local plant has only been studied in a few works (Belmont and Metcalfe, 2003; Zurita et al., 2006). Utilizing off-location plants on constructed wetlands may accelerate the plant damage, because the local plant can adapt easily to the site (Sieben et al., 2016a, 2016b).

Canna sp., Iris sp., Phragmites sp., and Typha $s p$. plants have been recommended as the leading species that can be grown in constructed wetlands because of their effectiveness in processing. Typha sp. can grow in different water depths, is easily transferred and transplanted, as well as has a wide tolerance to water composition, $\mathrm{pH}$, salinity, dissolved oxygen (DO), and contaminant concentration. Other popular Phragmites and Bulrush species are also commonly found in greywater management and blackwater management systems (Appenroth et al., 2010; Sohsalam and Sirianuntapiboon, 2008; Vymazal, 2011b). Many plant variations on constructed wetlands need to be evaluated with the single plant utilization in order to discover tha capabilities of each plant. Moges et al., (2016) developed 37 families with 122 plant species aimed at evaluating the natural condition of a constructed wetland in the long-term, considering that the selction of the right is still the subject of study for optimum performance of a constructed wetland (Brisson and Chazarenc, 2009; Gagnon et al., 2012). Haukos et al., (2016) evaluated the single plant role on a constructed wetland in Playa which removed approximately P 70\%, N 78\%, Total Dissolved Solids (TDS) 58\%, and Total Suspended Solids (TSS) $83 \%$. Processing using constructed wetlands occurs using various direct or indirect mechanisms (Brix, 1997; Greenway and Woolley, 2001; Shelef et al., 2013; Vymazal, 2013, 2011b).

The type of constructed wetlands such as runoff, vertical or horizontal flow, possible recirculation, and wastewater quality can affect the removal efficiency (Sklarz et al., 2009), the species and combination of plants (Brisson and Chazarenc, 2009), climate, types, and plant management. The research conducted by Ge et al., (2016) studied the effects of contaminant removal using different single plant utilizations of Thalia dealbata. This plant is known to be superior to Canna indica dan Lythrum salicaria in terms of removing $69.96 \%$ TN (Total Nitrogen) and 82.4\% TP (Total Phosphorus) from municipal rainwater runoff waste. Abou-Elela and Hellal, (2012) reported 91.5\% COD removal and $92.8 \%$ BOD removal on a constructed wetland planted with a variety of Canna indica, Cyperus papyrus, and Phragmites australis. Thus, the diverse plant utilization is considered to be more effective in reducing pollutants than the single plant utilization (Fraser et al., 2004; Karathanasis et al., 2003). The advantages of single plant utilization in a study of Qiu et al., (2011) showed that the growth of plants would be faster as well as produce higher biomass and nutrient uptake. The studies on single plant utilization indicated their several disadvantages, including susceptibility to seasonal changes, unstable growth of plants, and lower microbe population. The choice of single plant utilization on constructed wetlands can be used for single parameter wastes or for a singleparameter disposal purposes (Amon et al., 2007; Karathanasis et al., 2003).

\section{Diverse Plant Utilization}

Studies showed that different plants have various pollutant removal abilities; thus, the choice of plants is essential for constructed wetland impelementation (Brisson and Chazarenc, 2009; Vymazal and Kröpfelová, 2009). Most of the constructed wetlands around the world have low plant diversity or mainly used a single plant. One method to improve the pollutant removal is by increasing the plant diversity. The studies by Coleman et al., (2001) compared the removal pollutant removal using diverse plant and single plant on constructed wetlands, where the results were limited and some indicated that diverse plant utilization on constructed wetlands was better than the single plant utilization. The results of other studies comparing the pollutant removal of diverse plant and single plant showed varying results (Bachand and Horne, 1999; Coleman et al., 2001; Fraser et al., 2004; Karathanasis et al., 2003; Picard et al., 2005; Zhang et al., 2007a). Further studies are required to determine the differences in mechanisms between diverse plant utilization and single plant utilization (Brisson and Chazarenc, 2009; Coleman et al., 2001; Picard et al., 2005). Researchers have developed the advantages of diverse plant utilization on constructed wetlands (Fisher 
et al., 2009). Diverse plants are reported to have more benefits than single plants (Engelhardt and Ritchie, 2001; Tews et al., 2004). Constructed wetlands with diverse plants have a faster rate of removal of pollutant, because it is used for the plant growth; however, the selection of plants should be considered given the possibility of plant competition (Agami and Reddy, 1990; Engelhardt and Ritchie, 2001; Zhang et al., 2007b).

Diverse plant utilization has a higher efficiency than single plant utilization (Engelhardt and Ritchie, 2001; Tews et al., 2004; Samudro \& Mangkoedihardjo, 2020). The comparison of organic material removal on constructed wetlands with single plants and diverse plants is limited (Coleman et al., 2001). The limitation of single and diverse plant utilization result comparison is caused by different plant species utilization (Bachand and Horne, 1999; Coleman et al., 2001; Fraser et al., 2004; Karathanasis et al., 2003; Zhang et al., 2007a). Diverse plant utilization on constructed wetland aims to remove the pollutants with diverse contents; therefore, it is effective for obtaining environmentally friendly effluent. The plants applicable on constructed wetlands with a diverse plant system are Zantedeschia aethiopica and Strelitzia reginae (Zurita and White, 2014), Hymenocallis littoralis, Acorus calamus, Cyperus flabelliformis, Canna indica, and Phragmites australis (Qiu et al., 2011); they have the ability to reduce BOD and COD up to $90 \%$. Several studies using diverse plants did not demonstrate significant differences in organic material removals compared to single-plant constructed wetlands. Most of the constructed wetland systems were made of single plants from selected species.

Diverse plant utilization in constructed wetlands has neutral, positive, or negative correlation between plants and different species. Diverse-plant constructed wetland system has a more effective root biomass distribution and provides habitat for a more diverse microbe population than the single plant system (Coleman et al., 2001; Karathanasis et al., 2003; Karpiscak et al., 1996; Wu et al., 2012). Diverse plant utilization is reported to improve the root exudate release that increases the N and P absorptions (Wu et al., 2012). Diverseplant constructed wetland is superior to the singleplant. It has a slower growth rate and less, more stable biomass (Agami and Reddy, 1990; Zhang et al., 2007a). Despite not having significant differences between diverse plant utilization and single plant utilization, the diverse plant utilization is considered to be more effective in distributing biomass, not susceptible to seasonal variations, and has a more diverse microbe population than a single-plant constructed wetland (Amon et al., 2007; Karathanasis et al., 2003). A research indicating that diverse plant utilization is more effective than single plant utilization was also reported by Karathanasis et al., (2003). The diverse plant condition provides a more effective root distribution and a more favorable habitat that encourages high microbe community diversity. Diverse plant utilization has a diverse rooting system that postpones the wastewater flow and increases the retention time that affects the pollutant removal efficiency (Zurita and White, 2014). Diverse plant utilization in constructed wetlands should consider the fast/ slow plant growth, the rooting system including shallow/deep roots, seasonal growth patterns, resistance to aridity, tolerance to flood, and dominance. These are important to reduce the competition in diversity of plants in constructed wetlands.

Studies have shown that diverse plant utilization in constructed wetlands could create roots at different depths. Hence, it affects the rhizosphere microbe community that boosts the processing effectiveness (Amon et al., 2007). Zhang et al., (2007b) reported that Canna indica could defeat the Schoenoplectus validus' growth in a constructed wetland. Species competition may provide creation and growth that are favorable to particular species, and/or reduction and extinction of other species (Agami and Reddy, 1990). Many studies have examined the interspecies competition from the species in constructed wetlands. Wetzel and Van Der Valk, (1998) discovered that Phalaris arundinacea was a better competitor than Typha latifolia and Carex stricta. Coleman et al., (2001) also reported that Typha latifolia was superior in diverse plant utilization to Juncus effusus, Scirpus cyperius, and Typha latifolia. Qiu et al., (2011) discovered that Cyperus flabelliformis, Canna indica, and Phragmites australis are better competitors than Hymenocallis littoralis and Acorus calamus. These interspecies competitions generated positive effect, since it produced natural plants and ecosystem adaptation within a forced condition (Liang et al., 2011). Karathanasis et al., (2003) has examined diverse plant utilization of Iris, Bulrush, Cannae, and Hibiscus for household wastewater processing. The study concluded that the processing result was more consistent, efficient, and not susceptible to seasonal variations compared to single plant utilization. 
The elimination of pollutants from diverse plants used in constructed wetlands is due to the diversity of plant microbes (Perdana et al., 2018).
The differences between single plant and diverse plants in constructed wetland for treatment of pollutants can be seen in Table 1 .

Table 1. Previous data on single plants vs various plants

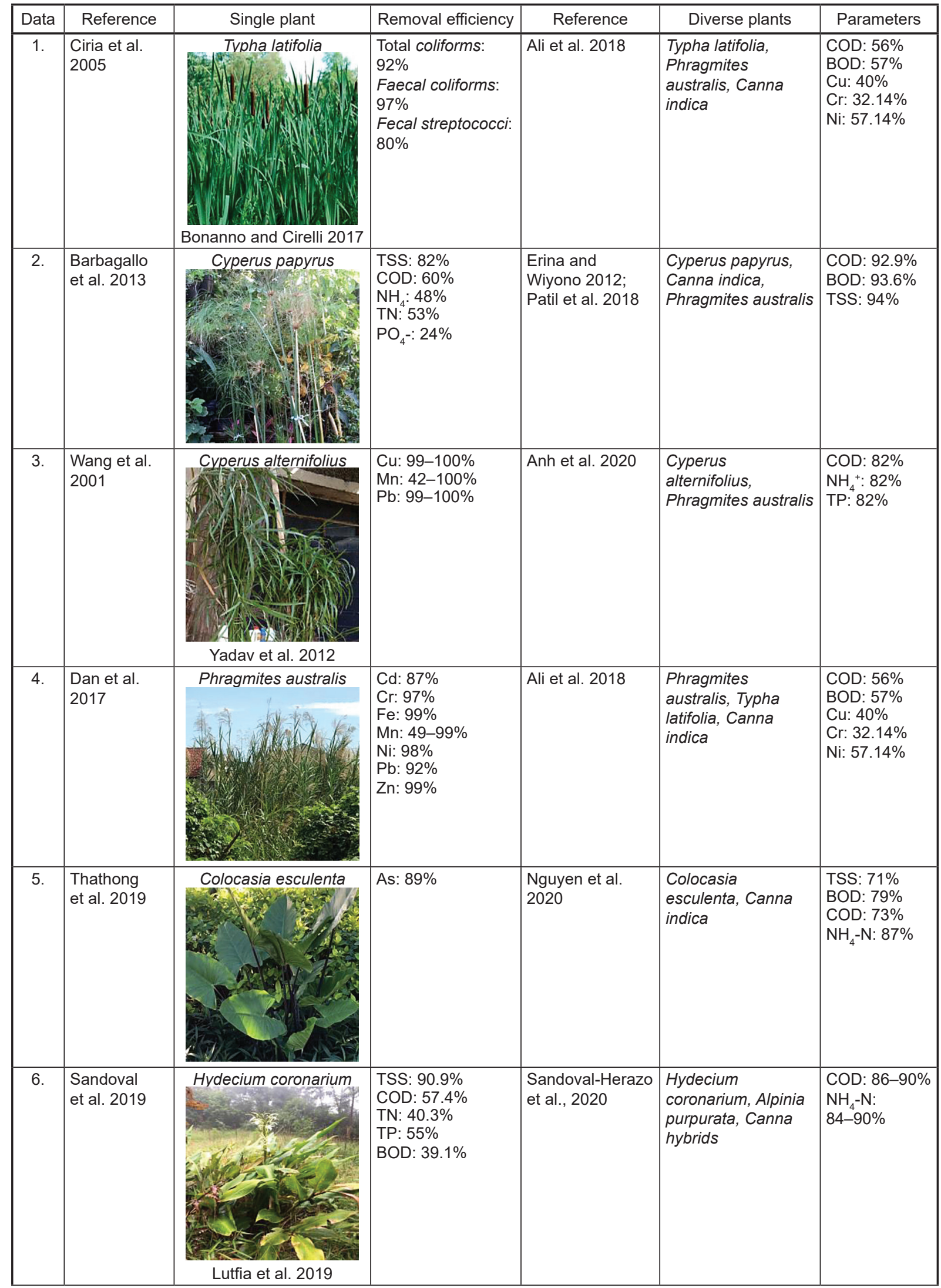


Table 1. Cont.

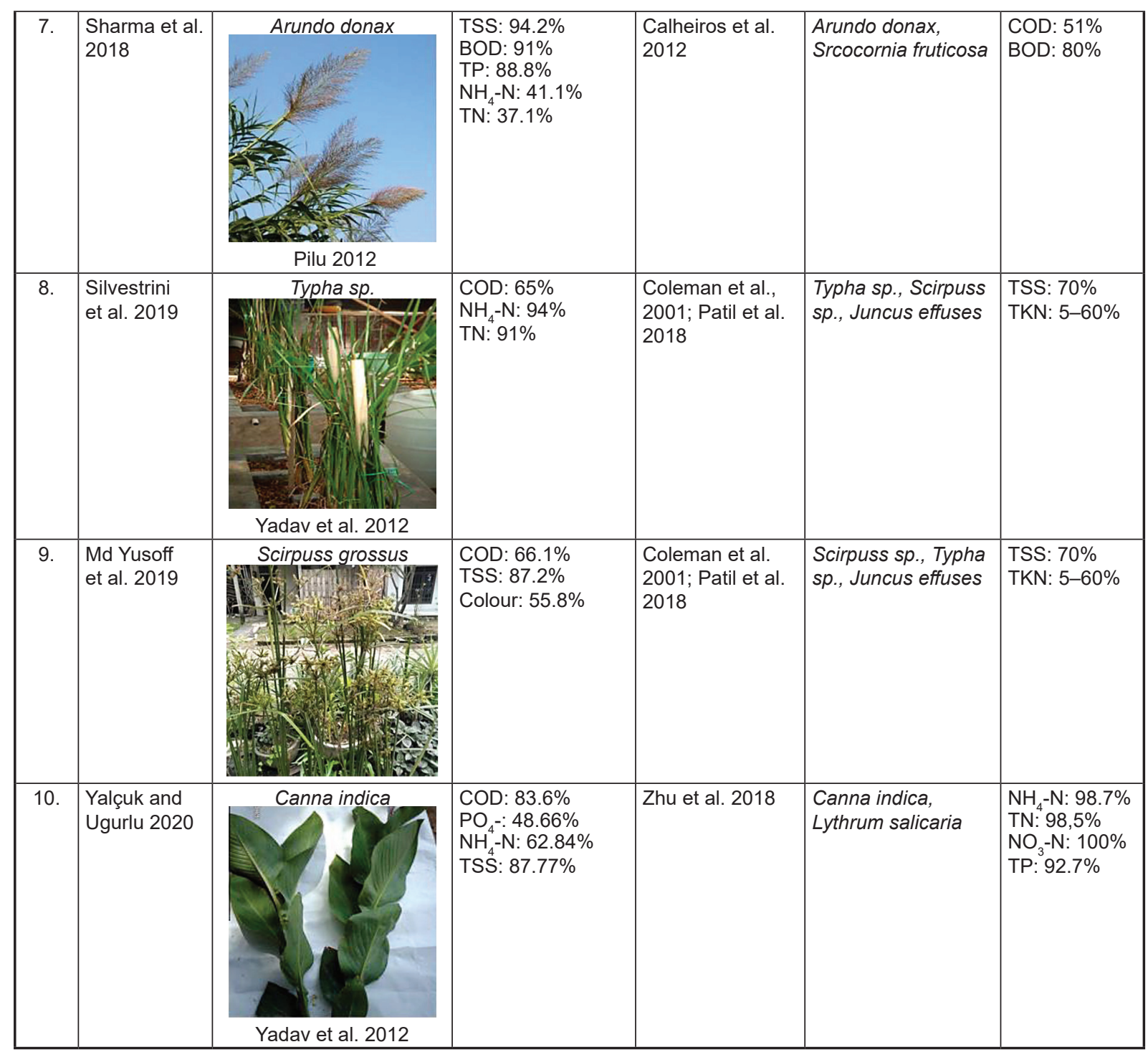

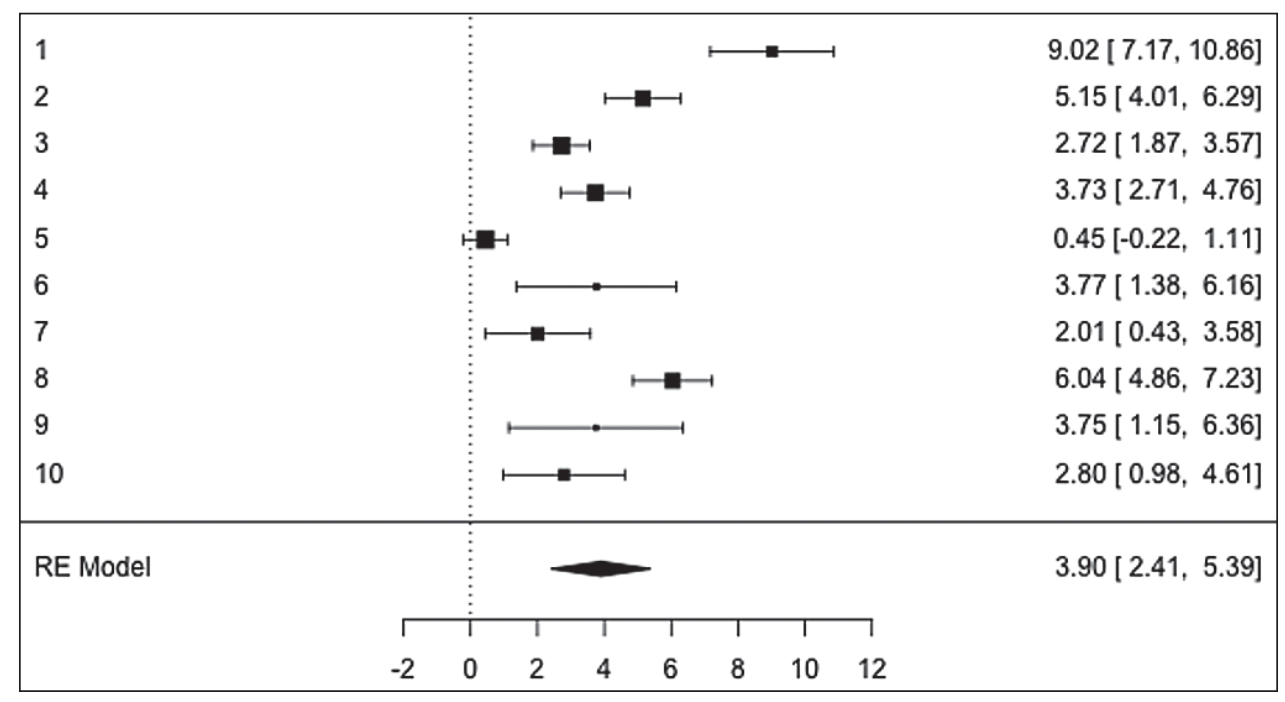

Figure 1. Forest plot single plant vs diverse plants 
Data obtained from previous studies were compared using single plants and multiple plants and analyzed using meta-analysis with jamovi software. A forest plot graph that compares the use of single plants and diverse plants from existing research can be seen in Figure 1.

The data extracted in data processing was used to calculate the effect sizes for each study. The effect size is a measure of the effect dimension being studied and can represent the differences between two groups, for example, the intervention and control groups, the gender group, the age group, or the strength of the relationship between the two groups of variables (Ellis, 2009). The data used in this review are the data on the differences between single and diverse plants. The most common effect sizes are based on the mean main effect size, binary data (risk ratio, chance ratio, and risk difference), correlation and survival data (hazard ratio). This review uses the removal efficiency effect resulting from processing with constructed wetlands. For each effect size, there are different data entry formats that can be used for the computational purposes (Borenstein et al., 2009).

Furthermore, for each study, the calculation of the magnitude of the effect is combined with the measurement of accuracy. Specifically, for each effect size of the variance, the standard error, and the $95 \%$ confidence interval were also calculated. As a convention, the statistical significance of the effect size is also reported (Cumming, 2014) in response to heightened concern that our published research literature is incomplete and untrustworthy, we need new requirements to ensure research integrity. These include prespecification of studies whenever possible, avoidance of selection and other inappropriate data-analytic practices, complete reporting, and encouragement of replication. Second, in response to renewed recognition of the severe flaws of null-hypothesis significance testing (NHST). It is good practice to report the effect sizes for each study in the forest plot (Moher et al., 2009). The results of the forest plot in Figure 1. show the effect size and the line represents the confidence interval (Hand, 2012). The results of the overall analysis are shown in the last section of the forest plot which can be seen in Table 2.
The next step, after calculating the overall effect size, consists in evaluating the heterogeneity across studies. In order to find out whether there is significant heterogeneity across studies answered using the $Q$ statistic, with a significant $Q$ value indicating significant heterogeneity of results between studies. The value of data heterogeneity can be seen from the $\mathrm{I}^{2}$ values (Huedo-Medina et al., 2006). Specifically, $\mathrm{I}^{2}$ estimates the proportion of observed variance that reflects a real difference in effect sizes, with values of $25 \%, 50 \%$, and $75 \%$ that might be effectively considered low, moderate, and high (Deeks, \& Altman, 2003). When the meta-analysis has little heterogeneity, it means that the primary study results are somewhat similar and consistent. However, in practice, it is very common to find significant and large heterogeneity (Crocetti, 2016).

This situation occurs especially when the meta-analysis includes 10 or more studies and each of them has answered the main research question differently from the others (for example, in different age groups and / or national samples, using different measures). The result is that while all results may be statistically significant, they can produce variations in the effect size considered (which can range from small to large). Thus, it was very common that the meta-analysis conducted in different areas highlight significant and large heterogeneity across study findings. In the results of the heterogeneity analysis reported in Table 2, the difference between single plant and diverse plants shows significant results as indicated by the Q statistic with a value of 141.255 and large heterogeneity, as shown by $\mathrm{I}^{2}$ of $93.06 \%$ (Crocetti, 2016).

\section{CONSTRUCTED WETLAND OPERATION}

\section{Operational and Implementation}

Constructed wetland is apotential alternative technology to improve the influent quality to be safe before through back to the environment, compared to the conventional method. Constructed wetland is a technology that has been applied since 1952 (Siedel, 1973) and fully operated since 1974 (Kickuth, 1977). Low-cost natural technologies engineered and designed for wastewater treatment

Table 2. Analysis result from the forest plot

\begin{tabular}{|c|c|c|c|c|c|c|c|}
\hline Tau & Tau $^{2}$ & $\mathrm{I}^{2}$ & $\mathrm{H}^{2}$ & $\mathrm{R}^{2}$ & $\mathrm{df}$ & $\mathrm{Q}$ & $\mathrm{p}$ \\
\hline 2.263 & $5.119(\mathrm{SE}=2.7109)$ & $93.06 \%$ & 14.406 & - & 9.0 & 141.255 & $<0.001$ \\
\hline
\end{tabular}


can be obtained in constructed wetlands (Wu et al., 2011; Zhang et al., 2010). A constructed wetland is an engineering system built by mimicking the process found in natural wastewater processing (Yeh et al., 2009). Natural processes used include plants, microbe, and soil activities that play role in the processing of toxic wastes. The interaction and correlation between microbes and plants are important for the performance of a constructed wetland system (Kadlec and Wallace, 2009; Vymazal, 2005). Other characteristics, such as different system construction and combination, flow characteristic, flow speed, different operational parameter effects, and different plant utilization also determine the ability and potentials of constructed wetland. Hence, a consideration should be taken so that a successfully constructed wetland can be obtained (Stefanakis et al., 2011). The combination of biological, chemical, and physical processes is responsible for removing contaminants from wastewater on constructed wetlands (Mthembu et al., 2013). The selection of suitable plants is very important to make it easier for plants to adapt, namely by utilizing macrophytes from the natural environment which form similar conditions in the execution site (Fadanelli et al., 2019; Samudro and Mangkoedihardjo, 2021). Plants should be shorn regularly and the rest removed to prevent decomposition and organic material accumulation that may inhibit new plants and change waste characteristics.

The choice of flow type on constructed wetland should be balanced with the capital and cost of land calculations (Kadlec and Wallace, 2009). Another consideration in constructed wetland is the management of plant biomass. Plant productivity is another parameter which must be considered and measured (Stefanakis, 2020). The design, construction, and system management management of appropriate systems of constructed wetland, such as types of flows, slope, and plant management are major factors in controlling disruptions such as usage of chemicals as mosquito controller (Knight et al., 2003; Walton, 2019). The implementation of constructed wetland should consider the area and water flow that aims to determine the characteristics of construction as well as maintenance that are likely to affect the selected system efficiency (Fadanelli et al., 2019). A constructed wetland technology has been implemented extensively and has a massive potential (Stefanakis, 2020). Constructed wetland functions are based on natural process which involves some interactions between primary system components, i.e., substrates, plants, wastewater, and microorganisms naturally growing (Stefanakis, 2015). Constructed wetland implementations in tackling pollution include catchment management series and domestic wastewater treatment (Denny, 1997).

\section{Leachate processing operation}

The liquid waste generated from rainwater percolating through solid wastes which are disposed of to landfills and humidity in wastes and waste degradation products is defined as landfill leachate (Costa et al., 2019). The number of produced leachate is influenced by rainfall, eco-transpiration, surface run off, groundwater infiltration, and landfills compaction rate (Miao et al., 2019). Several techniques are used to control the water inflows to landfills, including installing waterproof film and covering layer to minimize leachate (Dajić et al., 2016). The $\mathrm{pH}$, TSS, BOD, COD, TN, ammonia $\left(\mathrm{NH}_{4}-\mathrm{N}\right)$, phosphorus, chloride, alkalinity, and heavy metals are some of the physical and chemical parameters indicating the quality of landfill leachate (Bhatt et al., 2017). The biodegradability of landfill leachate declines over time, while the $\mathrm{COD} / \mathrm{BOD}_{5}$ ratio increases over time ( $>10$ years). Constructed wetlands are reported to have the potential to process toxic landfill leachate to be biodegradable. It constitutes an advantage compared to the conventional processes (Wojciechowska and Gajewska, 2013). The leachate characteristics determined based on landfill age are classified into three, namely young landfill of ( $<1$ year), medium landfill of (1-5 years), and old landfill of ( $>5$ years) (Abbas et al., 2009; Alvarez-Vazquez et al., 2004). The leachate characteristics based on landfill age are presented in Table 3.

COD concentration in leachate will decrease during the aging process of landfill, but the concentration of ammonia nitrogen increases (Kulikowska and Klimiuk, 2008). The leachate from young landfills contains biodegradable organic substances which can easily be transformed anaerobically into Volatile Fatty Acids (VFA) (Renou et al., 2008). VFA cause leachate from young landfills to have low $\mathrm{pH}$, high concentrations of $\mathrm{BOD}_{5}$ and COD (Kjeldsen et al., 2002), and high $\mathrm{BOD}_{5} / \mathrm{COD}$ ratio concentration (Purwanta, 2018). The old landfill has a low COD value, due to landfill aging, high concentrations of $\mathrm{NH}_{3}-\mathrm{N}$ and methane (Kjeldsen et al., 2002) as well as low $\mathrm{BOD}_{5} / \mathrm{COD}$ ratio (Purwanta, 2018). 
Table 3. Leachate characteristics based on landfill age

\begin{tabular}{|c|c|c|c|c|}
\hline \multirow{2}{*}{ Parameter } & \multicolumn{3}{|c|}{ Landfill age } & \multirow{2}{*}{ References } \\
\hline & Young (<1 year) & Medium ( $1-5$ years) & Old (> 5 years) & \\
\hline $\mathrm{pH}$ & $<6.5$ & $6.5-7.5$ & $>7.5$ & Peng 2017 \\
\hline $\operatorname{COD}\left(\mathrm{g} / \mathrm{m}^{3}\right)$ & $>15,000$ & $3,000-15,000$ & $<3,000$ & Abbas et al. 2009 \\
\hline BOD5/COD & $0.5-1.0$ & $0.1-0.5$ & $<0.1$ & Abbas et al. 2009 \\
\hline TSS $\left(g / m^{3}\right)$ & $340-540$ & - & $494-550$ & Ghani et al. 2017 \\
\hline Phenol $\left(\mathrm{g} / \mathrm{m}^{3}\right)$ & $3-1720$ & $0.01-316$ & - & Lee et al. 2010; Nagarajan et al. 2012 \\
\hline Color (Pt-Co) & $2,430-8,180$ & $3,900-4,250$ & $8,700-9,250$ & Azmi et al. 2015; Mohajeri et al. 2010 \\
\hline Turbidity (NTU) & $50-450$ & - & $15-286$ & Aziz et al. 2007; Mohd Zin et al. 2012 \\
\hline $\mathrm{TN}\left(\mathrm{g} / \mathrm{m}^{3}\right)$ & $75-3,200$ & $1,100-1,670$ & $141-960$ & Kulikowska and Klimiuk 2008 \\
\hline $\mathrm{NH}_{4}-\mathrm{N}\left(\mathrm{g} / \mathrm{m}^{3}\right)$ & $<400$ & - & $>400$ & Peng 2017 \\
\hline $\mathrm{NH}_{3}-\mathrm{N}\left(\mathrm{g} / \mathrm{m}^{3}\right)$ & $866-1,200$ & $743-1,330$ & $311-1,620$ & Ghani et al. 2017; Renou et al. 2008 \\
\hline Organic subtances & $80 \%$ VFA & $5-30 \%$ VFA+HA+FA & $\mathrm{HA}+\mathrm{FA}$ & Abbas et al. 2009 \\
\hline $\mathrm{Cd}\left(\mathrm{g} / \mathrm{m}^{3}\right)$ & $0.13-3.0$ & $0.02-0.05$ & $0.022-0.013$ & $\begin{array}{l}\text { Kulikowska and Klimiuk 2008; } \\
\text { Nagarajan et al. 2012; Sawaittayothin } \\
\text { and Polprasert } 2007\end{array}$ \\
\hline $\mathrm{Cr}\left(\mathrm{g} / \mathrm{m}^{3}\right)$ & 0.661 & $0.14-0.28$ & $0.05-0.08$ & $\begin{array}{l}\text { Kulikowska and Klimiuk 2008; } \\
\text { Nagarajan et al. 2012; Yilmaz et al. } 2010\end{array}$ \\
\hline $\mathrm{Cu}\left(\mathrm{g} / \mathrm{m}^{3}\right)$ & $0.1-0.4$ & $0.12-0.26$ & $0.01-0.09$ & $\begin{array}{l}\text { Azmi et al. 2015; Kulikowska and } \\
\text { Klimiuk } 2008\end{array}$ \\
\hline $\mathrm{Fe}\left(\mathrm{g} / \mathrm{m}^{3}\right)$ & $3.8-73.8$ & $58.4-63.4$ & $2.92-32.5$ & Lee et al. 2010; Nagarajan et al. 2012 \\
\hline $\mathrm{Ni}\left(\mathrm{g} / \mathrm{m}^{3}\right)$ & 0.385 & $0.31-0.38$ & $0.02-0.42$ & $\begin{array}{l}\text { Mohd Zin et al. 2012; Nagarajan et al. } \\
\text { 2012; Yilmaz et al. 2010 }\end{array}$ \\
\hline $\mathrm{Pb}\left(\mathrm{g} / \mathrm{m}^{3}\right)$ & 0.204 & $1.1-1.3$ & 0.07 & $\begin{array}{l}\text { Mohd Zin et al. 2012; Nagarajan et al. } \\
\text { 2012; Yilmaz et al. } 2010\end{array}$ \\
\hline $\mathrm{Zn}\left(\mathrm{g} / \mathrm{m}^{3}\right)$ & $0.1-1.8$ & $1.29-2.1$ & $0.22-0.435$ & $\begin{array}{l}\text { Azmi et al. 2015; Kulikowska and } \\
\text { Klimiuk 2008; Nagarajan et al. } 2012\end{array}$ \\
\hline
\end{tabular}

Constructed wetland utilization under hot climate has another process influencing the removal efficiency. In some cases, high water loss through EvapoTranspiration (ET) was found to exceed $40 \%$. Evapotranspiration is the evaporation and transpiration of plants that change the water balance in a constructed wetland system and cause salinity elevation (Stefanakis, 2020). Evapotranspiration is higher than water evaporation in open land under hot and dry climates (Headley et al., 2012; Pauliukonis and Schneider, 2001). The effluent from constructed wetland that is recovered should be considered to minimize the evapotranspiration. High evapotranspiration can be prevented through modification and simple design. The main parameter in dealing with this is the selection of plant species with less transpiration requirement, but high biomass productivity. The information regarding the quantity of plant water through transpiration per dry weight produced in local plants compared to different plants is highly needed (Touchette et al., 2007; Xiong et al., 2015). The constructed wetland system must also be designed with the least area possible so that it can improve the waste quality. A plausible constructed wetland implementation is also a consideration in an area. Before constructed wetland implementation under a hot climate, it is important to perform a study to identify the regional plant species to be used and to determine the water requirement in a laboratory-scale (Stefanakis, 2020).

A study by Yalçuk and Ugurlu, (2020) showed that although a $\mathrm{COD} / \mathrm{BOD}_{5}$ ratio of $>30$ the biodegradability was low, the organic removal efficiency was high. The oxygen produced by photosynthesis could replace the utilization of oxygen for organic mineralization and nitrification. The function of the plant is due to having roots to be used as a biofilm or where it sticks microbesthat dominate the pollutant degradation (Mohajeri et al., 2010). Plants facilitate the microbe degradation and oxygen transfer to the rhizosphere for biodegradation of landfill leachate. Yalçuk and Ugurlu, (2020) showed that oxygen was required for aerobic decomposition for COD, mainly due to the physical process such as filtration through the substrates, rather than the biological process related to plants. The result contrasts several studies which demonstrated that COD removal was higher due to the presence of plants, compared to non-plant systems 
(Naylor et al., 2003). Other studies emphasized that COD removal was not significantly affected by plants (Ayaz and Akça, 2001; Ciria et al., 2005; Wang et al., 2009). Leachate processing on tropical climate landfill with various concentrations can be conducted using constructed wetlands with efficiency $>90 \%$ using Equisentum hymale, Cyperus papyrus, Canna indica, and Hedychium coronarium, Arundo donax, Imperata cylindrica, and floating plant utilization of Eichornia crassipes, $S$. molesta, and Pistia stratiotes.

\section{LEACHATE PROCESSING PROTOCOL IN CONSTRUCTED WETLAND}

The toxicity of landfill leachate has been extensively tested by the bioassay method. The tool used to assess the risk of biota due to the pollutant is the bioassay (Klauck et al., 2015; Knie and Lopes, 2004). Toxicity tests are used to measure the number of substances exposed to an organism before the side effects of landfill leachate occur (Thomas et al., 2009). Toxicity testing using a bioassay, can represent chronic or acute exposure (Singh V, 2009). The preparation of toxicity tests with biological indicators needs to be peformed for biota based on economics, type of test, sensitivity, and consistency of response (Hueck-Van der Plas and Hueck, 1979; Landis et al., 2003). The organisms used as biological indicators for the toxicity test of landfill leachate are varied, including bacteria, green algae, fish, and others (Thomas et al., 2009). Chemical analysis is a conventional landfill leachate toxicity test based on the evaluation of identified chemical organisms. Chemical evaluation does not evaluate the toxic effects, so the biological evaluation is required (Umi Raihana et al., 2014). Biological evaluation integrates the biological effects of all the other factors, such as toxic and bioavailability interactions, and the compounds present (Žaltauskaite and Čypaite, 2008; Mangkoedihardjo and Samudro, 2014). The phytotoxicity test is a toxicity test method that is widely used, because it is fast, accurate, high sensitivity, simple, low cost, and suitable for chemicals or unstable substances (Wang et al., 2001). The toxicity test results were represented by the value of Effect Concentration (EC-50) non-toxic $>100$, potentially toxic $100>\mathrm{EC}-50>$ 40 , toxic $40>$ EC-50> 10 , EC-50 very toxic $<9$ (Zanelato et al., 2019). According to Restrepo,
(2013) in Zanelato et al., (2019), the high toxicity of landfill leachate is related to the mixing of organic and synthetic substances, which results in chemical reactions leading to the dissolution of toxic substances from solid objects into the water phase. Leachate toxicity test on parrotfish ( $\mathrm{Sa}$ rotherodon mossambicus) with Lethal Concentration (LC-50) 1.4 and $12 \% \mathrm{v} / \mathrm{v}$ in two months (Angaye and Seiyaboh, 2019; Wong, 1989). The leachate toxicity test used Tawes fish, and the results showed an LC-50 value of $0.358 \%$, with clinical symptoms in the form of bulging eyes and brown skin (Juliardi and Wiyanti, 2018). The smaller of EC-50 or LC-50 value indicates that the substance is increasingly harmful to biota.

Plants also act as intermediaries to remove pollutants by increasing the environmental diversity in the rhizosphere (Gagnon et al., 2012; Stottmeister et al., 2003; Vymazal, 2011a; Zahui et al., 2018). Various operating conditions such as flow rates, climate, high levels of organic matter and nutrients, and fluctuating pollution loads are required for different plant species (Vymazal, 2007). The nitrogen and phosphorus removal can vary based on variations in the rate of sediment oxidation, carbon supply, and transpiration, and plant species can respond differently after harvest (Greenway and Woolley, 2001; Wu et al., 2013b, 2013a, 2011).

The adaptation of new community habits prevents and slows down the virus, disease, and spread of COVID-19 (Yari et al., 2020). Washing hands or disinfecting items such as utensils, door handles, tables and chairs, valves, stair railings, switches, electrical outlets, and all common items, such as banknotes and documents, is essential (Jin et al., 2020; Organization, 2020; Van Doremalen et al., 2020). Prevention of the spread of disease through contact with people or objects is achieved via antiseptics and disinfectants. The use of antiseptic and disinfectant by the community has the potential to enter the landfill. The content of antiseptic and disinfectant in landfills can dissolve in leachate; then, it enters the environment. The content of landfill leachate in the form of toxic organic substances and chlorides from disinfectants that enter the landfill can be detoxified by processing using plants (Samudro and Mangkoedihardjo, 2020).

\section{CONCLUSIONS}

Landfill leachate contains various kinds of toxic pollutants. The landfill leachate toxicity test 
could be undertaken using the bioassay method. Bioassays for toxicity testing could use organisms such as fish, microorganisms, and plants (phytotoxicity). The phytotoxicity analysis process stages analysed the sources and distribution of pollutants, the transportation and transformation of substances in plants, and the responses of plants that occurred. The toxic content in landfill leachate could be processed by physical and chemical methods at the beginning of processing to increase the quality to become biodegradable. Further, processing was carried out to increase the stability of the quality of landfill leachate through biological processing such as constructed wetlands. Constructed wetlands with a variety of plants indicated that a better microbial community structure and stable plant growth. The criteria of design and operation covered the selection of location, substrate choice, types of wastewater, material choice, water depth, HLR, HRT, and maintenance procedure.

\section{Acknowledements}

The authors would like to show gratitude to The Ministry of Research and Technology, Program of Research Technology National Research and Innovation Agency in the PMDSU program.

\section{REFERENCES}

1. Abbas, A.A., Jingsong, G., Ping, L.Z., Ya, P.Y., Al-Rekabi, W.S., 2009. Review on landfill leachate treatments. Am. J. Appl. Sci. https://doi. org/10.3844/ajas.2009.672.684

2. Abou-Elela, S.I., Hellal, M.S., 2012. Municipal wastewater treatment using vertical flow constructed wetlands planted with Canna, Phragmites and Cyprus. Ecol. Eng. https://doi.org/10.1016/j. ecoleng.2012.06.044

3. Agami, M., Reddy, K.R., 1990. Competition for space between Eichhornia crassipes (Mart.) Solms and Pistia stratiotes L. cultured in nutrient-enriched water. Aquat. Bot. https://doi. org/10.1016/0304-3770(90)90005-6

4. Akinbile, C.O., Yusoff, M.S., Ahmad Zuki, A.Z., 2012. Landfill leachate treatment using subsurface flow constructed wetland by Cyperus haspan. Waste Manag. https://doi.org/10.1016/j. wasman.2012.03.002

5. Ali, Z., Mohammad, A., Riaz, Y., Quraishi, U.M., Malik, R.N., 2018. Treatment efficiency of a hybrid constructed wetland system for municipal wastewater and its suitability for crop irrigation. Int. J. Phytoremediation 20, 1152-1161.
6. Alvarez-Vazquez, H., Jefferson, B., Judd, S.J., 2004. Membrane bioreactors vs conventional biological treatment of landfill leachate: a brief review. J. Chem. Technol. Biotechnol. Int. Res. Process. Environ. Clean Technol. 79, 1043-1049.

7. Amon, J.P., Agrawal, A., Shelley, M.L., Opperman, B.C., Enright, M.P., Clemmer, N.D., Slusser, T., Lach, J., Sobolewski, T., Gruner, W., Entingh, A.C., 2007. Development of a wetland constructed for the treatment of groundwater contaminated by chlorinated ethenes. Ecol. Eng. https://doi.org/10.1016/j. ecoleng.2007.01.008

8. Angaye, T.C.N., Seiyaboh, E.I., 2019. Ecotoxicological Assessment of Leachate From Municipal Solid Waste Dumpsites. J. Exp. Clin. Toxicol. 1, 31.

9. Appenroth, K.J., Krech, K., Keresztes, Á., Fischer, W., Koloczek, H., 2010. Effects of nickel on the chloroplasts of the duckweeds Spirodela polyrhiza and Lemna minor and their possible use in biomonitoring and phytoremediation. Chemosphere. https:// doi.org/10.1016/j.chemosphere.2009.11.007

10. Ayaz, S.Ç., Akça, L., 2001. Treatment of wastewater by natural systems. Environ. Int. https://doi. org/10.1016/S0160-4120(00)00099-4

11. Bachand, P.A.M., Horne, A.J., 1999. Denitrification in constructed free-water surface wetlands: II. Effects of vegetation and temperature. Ecol. Eng. https://doi.org/10.1016/S0925-8574(99)00017-8

12. Bakhshoodeh, R., Alavi, N., Oldham, C., Santos, R.M., Babaei, A.A., Vymazal, J., Paydary, P., 2020. Constructed wetlands for landfill leachate treatment: A review. Ecol. Eng. https://doi.org/10.1016/j. ecoleng.2020.105725

13. Barlaz, M.A., Rooker, A.P., Kjeldsen, P., Gabr, M.A., Borden, R.C., 2002. Critical evaluation of factors required to terminate the postclosure monitoring period at solid waste landfills. Environ. Sci. Technol. https://doi.org/10.1021/es011245u

14. Belmont, M.A., Cantellano, E., Thompson, S., Williamson, M., Sánchez, A., Metcalfe, C.D., 2004. Treatment of domestic wastewater in a pilot-scale natural treatment system in central Mexico. Ecol. Eng. https://doi.org/10.1016/j.ecoleng.2004.11.003

15. Belmont, M.A., Metcalfe, C.D., 2003. Feasibility of using ornamental plants (Zantedeschia aethiopica) in subsurface flow treatment wetlands to remove nitrogen, chemical oxygen demand and nonylphenol ethoxylate surfactants - A laboratory-scale study. Ecol. Eng. https://doi.org/10.1016/j.ecoleng.2003.10.003

16. Bhatt, A.H., Karanjekar, R. V., Altouqi, S., Sattler, M.L., Hossain, M.D.S., Chen, V.P., 2017. Estimating landfill leachate BOD and COD based on rainfall, ambient temperature, and waste composition: Exploration of a MARS statistical approach. Environ. Technol. Innov. https://doi.org/10.1016/j.eti.2017.03.003

17. Białowiec, A., Davies, L., Albuquerque, A., Randerson, P.F., 2012. The influence of plants on nitrogen removal from landfill leachate in discontinuous 
batch shallow constructed wetland with recirculating subsurface horizontal flow. Ecol. Eng. https:// doi.org/10.1016/j.ecoleng.2011.12.011

18. Borenstein, M., Hedges, L. V., Higgins, J.P.T., Rothstein, H.R., 2009. Introduction to Meta-Analysis, Introduction to Meta-Analysis. https://doi. org/10.1002/9780470743386

19. Borglin, S.E., Hazen, T.C., Oldenburg, C.M., Zawislanski, P.T., 2004. Comparison of aerobic and anaerobic biotreatment of municipal solid waste. J. Air Waste Manag. Assoc. https://doi.org/10.1080/1 0473289.2004.10470951

20. Brisson, J., Chazarenc, F., 2009. Maximizing pollutant removal in constructed wetlands: Should we pay more attention to macrophyte species selection? Sci. Total Environ. https://doi.org/10.1016/j. scitotenv.2008.05.047

21. Brix, H., 1997. Do macrophytes play a role in constructed treatment wetlands?, in: Water Science and Technology. https://doi.org/10.1016/ S0273-1223(97)00047-4

22. Çeçen, F., Çakıroğlu, D., 2001. Impact of landfill leachate on the co-treatment of domestic wastewater. Biotechnol. Lett. 23, 821-826.

23. Ciria, M.P., Solano, M.L., Soriano, P., 2005. Role of macrophyte Typha latifolia in a constructed wetland for wastewater treatment and assessment of its potential as a biomass fuel. Biosyst. Eng. https://doi. org/10.1016/j.biosystemseng.2005.08.007

24. Coleman, J., Hench, K., Garbutt, K., Sexstone, A., Bissonnette, G., Skousen, J., 2001. Treatment of domestic wastewater by three plant species in constructed wetlands. Water. Air. Soil Pollut. https:// doi.org/10.1023/A:1010336703606

25. Costa, A.M., Alfaia, R.G. de S.M., Campos, J.C., 2019. Landfill leachate treatment in Brazil-An overview. J. Environ. Manage. https://doi.org/10.1016/j. jenvman.2018.11.006

26. Crocetti, E., 2016. Systematic Reviews With MetaAnalysis: Why, When, and How? Emerg. Adulthood 4,3-18. https://doi.org/10.1177/2167696815617076

27. Cumming, G., 2014. The New Statistics: Why and How. Psychol. Sci. https://doi. org/10.1177/0956797613504966

28. Dajić, A., Mihajlović, M., Jovanović, M., Karanac, M., Stevanović, D., Jovanović, J., 2016. Landfill design: Need for improvement of water and soil protection requirements in EU Landfill Directive. Clean Technol. Environ. Policy. https://doi.org/10.1007/ s10098-015-1046-2

29. Dallas, S., Ho, G., 2005. Subsurface flow reedbeds using alternative media for the treatment of domestic greywater in Monteverde, Costa Rica, Central America. Water Sci. Technol. https://doi. org/10.2166/wst.2005.0358

30. Denny, P., 1997. Implementation of constructed wetlands in developing countries, in: Water
Science and Technology. https://doi.org/10.1016/ S0273-1223(97)00049-8

31. Ellis, P.D., 2009. The Essential Guide to Effect Sizes: An Introduction to Statistical Power, Meta-Analysis and the Interpretation of Research Results. Power.

32. Engelhardt, K.A.M., Ritchie, M.E., 2001. Effects of macrophyte species richness on wetland ecosystem functioning and services. Nature. https://doi. org/10.1038/35079573

33. Fadanelli, L.E.A., De Andrade Filho, A.G., Wiecheteck, G.K., Döll, M.M.R., 2019. Considerations on design and implementation parameters of domestic wastewater treatment by subsurface flow constructed wetlands. Eng. Sanit. e Ambient. https:// doi.org/10.1590/s1413-41522019102334

34. Fang, Z., Cao, X., Li, Xuexiao, Wang, H., Li, Xianning, 2017. Electrode and azo dye decolorization performance in microbial-fuel-cell-coupled constructed wetlands with different electrode size during long-term wastewater treatment. Bioresour. Technol. https://doi.org/10.1016/j.biortech.2017.04.075

35. Fisher, J., Stratford, C.J., Buckton, S., 2009. Variation in nutrient removal in three wetland blocks in relation to vegetation composition, inflow nutrient concentration and hydraulic loading. Ecol. Eng. https://doi.org/10.1016/j.ecoleng.2009.05.009

36. Fraser, L.H., Carty, S.M., Steer, D., 2004. A test of four plant species to reduce total nitrogen and total phosphorus from soil leachate in subsurface wetland microcosms. Bioresour. Technol. https://doi. org/10.1016/j.biortech.2003.11.023

37. Gagnon, V., Chazarenc, F., Kõiv, M., Brisson, J., 2012. Effect of plant species on water quality at the outlet of a sludge treatment wetland. Water Res. https://doi.org/10.1016/j.watres.2012.07.007

38. Gao, J., Oloibiri, V., Chys, M., Audenaert, W., Decostere, B., He, Y., Van Langenhove, H., Demeestere, K., Van Hulle, S.W.H., 2014. The present status of landfill leachate treatment and its development trend from a technological point of view. Rev. Environ. Sci. Biotechnol. https://doi.org/10.1007/s11157-014-9349-z

39. Ge, Z., Feng, C., Wang, X., Zhang, J., 2016. Seasonal applicability of three vegetation constructed floating treatment wetlands for nutrient removal and harvesting strategy in urban stormwater retention ponds. Int. Biodeterior. Biodegrad. https://doi. org/10.1016/j.ibiod.2016.05.007

40. Greenway, M., Woolley, A., 2001. Changes in plant biomass and nutrient removal over 3 years in a constructed wetland in Cairns, Australia, in: Water Science and Technology. https://doi.org/10.2166/wst.2001.0844

41. Hand, D.J., 2012. Understanding The New Statistics: Effect Sizes, Confidence Intervals, and MetaAnalysis by Geoff Cumming. Int. Stat. Rev. https:// doi.org/10.1111/j.1751-5823.2012.00187_26.x

42. Haukos, D.A., Johnson, L.A., Smith, L.M., McMurry, S.T., 2016. Effectiveness of vegetation buffers surrounding playa wetlands at contaminant and 
sediment amelioration. J. Environ. Manage. https:// doi.org/10.1016/j.jenvman.2016.07.011

43. Headley, T.R., Davison, L., Huett, D.O., Müller, R., 2012. Evapotranspiration from subsurface horizontal flow wetlands planted with Phragmites australis in sub-tropical Australia. Water Res. https://doi. org/10.1016/j.watres.2011.10.042

44. Hueck-Van der Plas, E.H., Hueck, H.J., 1979. The prospective assessment of environmental effects of chemicals, in: Drug Design. Elsevier, pp. 311-354.

45. Huedo-Medina, T., Sanchez-Meca, J., Marin-Martinez, F., Botella, J., 2006. Assessing heterogeneity in metaanalysis: Q statistic or I2 index? Part of the Psychology Commons Recommended Citation. Psychol. Methods.

46. Idris, A., Inanc, B., Hassan, M.N., 2004. Overview of waste disposal and landfills/dumps in Asian countries. J. Mater. Cycles Waste Manag. https:// doi.org/10.1007/s10163-004-0117-y

47. Iskander, S.M., Zhao, R., Pathak, A., Gupta, A., Pruden, A., Novak, J.T., He, Z., 2018. A review of landfill leachate induced ultraviolet quenching substances: Sources, characteristics, and treatment. Water Res. https://doi.org/10.1016/j.watres.2018.08.035

48. Jin, Y.H., Cai, L., Cheng, Z.S., Cheng, H., Deng, T., Fan, Y.P., Fang, C., Huang, D., Huang, L.Q., Huang, Q., Han, Y., Hu, B., Hu, F., Li, B.H., Li, Y.R., Liang, K., Lin, L.K., Luo, L.S., Ma, J., Ma, L.L., Peng, Z.Y., Pan, Y.B., Pan, Z.Y., Ren, X.Q., Sun, H.M., Wang, Y., Wang, Yun Yun, Weng, H., Wei, C.J., Wu, D.F., Xia, J., Xiong, Y., Xu, H.B., Yao, X.M., Yuan, Y.F., Ye, T.S., Zhang, X.C., Zhang, Y.W., Zhang, Y.G., Zhang, H.M., Zhao, Y., Zhao, M.J., Zi, H., Zeng, X.T., Wang, Yong Yan, Wang, X.H., 2020. A rapid advice guideline for the diagnosis and treatment of 2019 novel coronavirus (2019-nCoV) infected pneumonia (standard version). Mil. Med. Res. https://doi.org/10.1186/s40779-020-0233-6

49. Juliardi, A.R.N.R., Wiyanti, R.I., 2018. The test ability of fish Tawes to leachate garbage dump (TPA) Benowo, in: Journal of Physics: Conference Series. https://doi.org/10.1088/1742-6596/953/1/012223

50. Kadlec, R.H., Wallace, S.D., 2009. Treatment Wetlands, Second Edition, Treatment Wetlands, Second Edition. https://doi.org/10.1201/9781420012514

51. Karathanasis, A.D., Potter, C.L., Coyne, M.S., 2003. Vegetation effects on fecal bacteria, BOD, and suspended solid removal in constructed wetlands treating domestic wastewater. Ecol. Eng. https://doi. org/10.1016/S0925-8574(03)00011-9

52. Karpiscak, M.M., Gerba, C.P., Watt, P.M., Foster, K.E., Falabi, J.A., 1996. Multi-species plant systems for wastewater quality improvements and habitat enhancement, in: Water Science and Technology. https://doi.org/10.1016/0273-1223(96)00424-6

53. Khan, S., Ahmad, I., Shah, M.T., Rehman, S., Khaliq, A., 2009. Use of constructed wetland for the removal of heavy metals from industrial wastewater. J. Environ. Manage. https://doi.org/10.1016/j. jenvman.2009.05.026

54. Kickuth, R., 1977. Degradation and incorporation of nutrients from rural wastewaters by plant rhizosphere under limnic conditions. Util. manure by L. spreading 335-343.

55. Kjeldsen, P., Barlaz, M.A., Rooker, A.P., Baun, A., Ledin, A., Christensen, T.H., 2002. Present and long-term composition of MSW landfill leachate: A review. Crit. Rev. Environ. Sci. Technol. https:// doi.org/10.1080/10643380290813462

56. Klauck, C., Rodrigues, M., Silva, L., 2015. Evaluation of phytotoxicity of municipal landfill leachate before and after biological treatment. Brazilian J. Biol. https://doi.org/10.1590/1519-6984.1813

57. Knie, J.L.W., Lopes, E.W.B., 2004. Testes ecotoxicológicos: métodos, técnicas e aplicações.

58. Knight, R.L., Walton, W.E., O’Meara, G.F., Reisen, W.K., Wass, R., 2003. Strategies for effective mosquito control in constructed treatment wetlands. Ecol. Eng. https://doi.org/10.1016/j.ecoleng.2003.11.001

59. Kulikowska, D., Klimiuk, E., 2008. The effect of landfill age on municipal leachate composition. Bioresour. Technol. https://doi.org/10.1016/j. biortech.2007.10.015

60. Kurniawan, T.A., Lo, W.H., Chan, G.Y.S., 2006. Physico-chemical treatments for removal of recalcitrant contaminants from landfill leachate. J. Hazard. Mater. https://doi.org/10.1016/j. jhazmat.2005.08.010

61. Landis, W., Sofield, R., Yu, M.-H., Landis, W.G., 2003. Introduction to Environmental Toxicology: Impacts of Chemicals Upon Ecological Systems, Third Edition, CRC Press.

62. Li, Y., Zhu, G., Ng, W.J., Tan, S.K., 2014. A review on removing pharmaceutical contaminants from wastewater by constructed wetlands: Design, performance and mechanism. Sci. Total Environ. https://doi.org/10.1016/j.scitotenv.2013.09.018

63. Liang, M.Q., Zhang, C.F., Peng, C.L., Lai, Z.L., Chen, D.F., Chen, Z.H., 2011. Plant growth, community structure, and nutrient removal in monoculture and mixed constructed wetlands. Ecol. Eng. https://doi.org/10.1016/j.ecoleng.2010.11.018

64. Luo, H., Zeng, Y., Cheng, Y., He, D., Pan, X., 2020. Recent advances in municipal landfill leachate: A review focusing on its characteristics, treatment, and toxicity assessment. Sci. Total Environ. 703, 135468. https://doi.org/10.1016/j.scitotenv.2019.135468

65. Mangkoedihardjo, S., Samudro, G. 2014. Research strategy on kenaf for phytoremediation of organic matter and metals polluted soil. Advances in Environmental Biology, 8(17), 64-67.

66. Miao, L., Yang, G., Tao, T., Peng, Y., 2019. Recent advances in nitrogen removal from landfill leachate using biological treatments - A review. J. Environ. Manage. https://doi.org/10.1016/j. jenvman.2019.01.057 
67. Moges, A., Beyene, A., Kelbessa, E., Mereta, S.T., Ambelu, A., 2016. Development of a multimetric plant-based index of biotic integrity for assessing the ecological state of forested, urban and agricultural natural wetlands of Jimma Highlands, Ethiopia. Ecol. Indic. https://doi.org/10.1016/j.ecolind.2016.06.057

68. Mohajeri, S., Aziz, H.A., Isa, M.H., Bashir, M.J.K., Mohajeri, L., Adlan, M.N., 2010. Influence of Fenton reagent oxidation on mineralization and decolorization of municipal landfill leachate. J. Environ. Sci. Heal. - Part A Toxic/Hazardous Subst. Environ. Eng. https://doi.org/10.1080/10934521003648883

69. Moher, D., Liberati, A., Tetzlaff, J., Altman, D.G., Altman, D., Antes, G., Atkins, D., Barbour, V., Barrowman, N., Berlin, J.A., Clark, J., Clarke, M., Cook, D., D’Amico, R., Deeks, J.J., Devereaux, P.J., Dickersin, K., Egger, M., Ernst, E., Gøtzsche, P.C., Grimshaw, J., Guyatt, G., Higgins, J., Ioannidis, J.P.A., Kleijnen, J., Lang, T., Magrini, N., McNamee, D., Moja, L., Mulrow, C., Napoli, M., Oxman, A., Pham, B., Rennie, D., Sampson, M., Schulz, K.F., Shekelle, P.G., Tovey, D., Tugwell, P., 2009. Preferred reporting items for systematic reviews and meta-analyses: The PRISMA statement. PLoS Med. https://doi.org/10.1371/journal.pmed.1000097

70. Mojiri, A., Aziz, H.A., Aziz, S.Q., 2013. Trends in Physical-Chemical Methods for Landfill Leachate Treatment. Int. J. Sci. Res. Environ. Sci. https://doi. org/10.12983/ijsres-2013-p016-025

71. Moshiri, G.A., Brix, H., 2020. Wastewater Treatment in Constructed Wetlands: System Design, Removal Processes, and Treatment Performance, in: Constructed Wetlands for Water Quality Improvement. https://doi.org/10.1201/9781003069997-3

72. Mthembu, M., Odinga, C., Swalaha, F., Bux, F., 2013. Constructed wetlands: A future alternative wastewater treatment technology. African J. Biotechnol. https://doi.org/10.5897/ajb2013.12978

73. Naylor, S., Brisson, J., Labelle, M.A., Drizo, A., Comeau, Y., 2003. Treatment of freshwater fish farm effluent using constructed wetlands: The role of plants and substrate, in: Water Science and Technology. https://doi.org/10.2166/wst.2003.0324

74. Nguyen, X.C., Tran, T.C.P., Hoang, V.H., Nguyen, T.P., Chang, S.W., Nguyen, D.D., Guo, W., Kumar, A., La, D.D., Bach, Q.V., 2020. Combined biochar vertical flow and free-water surface constructed wetland system for dormitory sewage treatment and reuse. Sci. Total Environ. https://doi.org/10.1016/j. scitotenv.2019.136404

75. Nivala, J., Hoos, M.B., Cross, C., Wallace, S., Parkin, G., 2007. Treatment of landfill leachate using an aerated, horizontal subsurface-flow constructed wetland. Sci. Total Environ. https://doi.org/10.1016/j. scitotenv.2006.12.030

76. Organization, W.H., 2020. Health Topics. Coronavírus. Coronavirus symptoms. World Heal. Organ. 2020a. Disponível em https//www. who. int/ healthtopics/coronavirus $\#$ tab $=$ tab 3 . Acesso em 7 .

77. Pauliukonis, N., Schneider, R., 2001. Temporal patterns in evapotranspiration from lysimeters with three common wetland plant species in the eastern United States. Aquat. Bot. https://doi.org/10.1016/ S0304-3770(01)00168-1

78. Perdana, M.C., Sutanto, H.B., Prihatmo, G., 2018. Vertical Subsurface Flow (VSSF) constructed wetland for domestic wastewater treatment, in: IOP Conference Series: Earth and Environmental Science. https://doi.org/10.1088/1755-1315/148/1/012025

79. Picard, C.R., Fraser, L.H., Steer, D., 2005. The interacting effects of temperature and plant community type on nutrient removal in wetland microcosms. Bioresour. Technol. https://doi.org/10.1016/j. biortech.2004.09.007

80. Purwanta, W., 2018. Tinjauan teknologi pengolahan leachate di tempat pembuangan akhir (TPA) sampah perkotaan. J. Air Indones. https://doi.org/10.29122/ jai.v3i1.2318

81. Qiu, Z.C., Wang, M., Lai, W.L., He, F.H., Chen, Z.H., 2011. Plant growth and nutrient removal in constructed monoculture and mixed wetlands related to stubble attributes. Hydrobiologia. https:// doi.org/10.1007/s10750-010-0530-2

82. Renou, S., Givaudan, J.G., Poulain, S., Dirassouyan, F., Moulin, P., 2008. Landfill leachate treatment: Review and opportunity. J. Hazard. Mater. https://doi. org/10.1016/j.jhazmat.2007.09.077

83. Restrepo, J.J.B., 2013. Determinação da taxa de transferência de elementos-traço de resíduos sólidos urbanos para lixiviado.

84. Samudro, G., Mangkoedihardjo, S. 2020. Mixed plant operations for phytoremediation in polluted environments - A critical review. Journal of Phytology, 12, 99-103. https://doi.org/https://doi. org/10.25081/jp.2020.v12.6454

85. Samudro, H., Mangkoedihardjo, S., 2020. Greening the environment in living a new lifestyle in the COVID-19 era. Eurasian J. Biosci. 14, 3285-3290.

86. Samudro, H., Mangkoedihardjo, S. 2021. Indoor phytoremediation using decorative plants: An overview of application principles. Journal of Phytology, 13, 28-32. https://doi.org/https://doi.org/10.25081/ jp.2021.v13.6866

87. Sandoval, L., Zamora-Castro, S.A., Vidal-Álvarez, M., Marín-Muñiz, J.L., 2019. Role of wetland plants and use of ornamental flowering plants in constructed wetlands for wastewater treatment: A review. Appl. Sci. https://doi.org/10.3390/app9040685

88. Sharma, G., Priya, Brighu, U., 2014. Performance Analysis of Vertical Up-flow Constructed Wetlands for Secondary Treated Effluent. APCBEE Procedia. https://doi.org/10.1016/j.apcbee.2014.10.026

89. Shelef, O., Gross, A., Rachmilevitch, S., 2013. Role of plants in a constructed wetland: current and new perspectives. Water 5, 405-419. 
90. Sieben, E.J.J., Collins, N.B., Mtshali, H., Venter, C.E., 2016a. The vegetation of inland wetlands with salt-tolerant vegetation in South Africa: Description, classification and explanatory environmental factors. South African J. Bot. https://doi.org/10.1016/j. sajb.2015.11.004

91. Sieben, E.J.J., Nyambeni, T., Mtshali, H., Corry, F.T.J., Venter, C.E., MacKenzie, D.R., Matela, T.E., Pretorius, L., Kotze, D.C., 2016b. The herbaceous vegetation of subtropical freshwater wetlands in South Africa: Classification, description and explanatory environmental factors. South African J. Bot. https://doi.org/10.1016/j.sajb.2015.11.005

92. Siedel, K., 1973. Patent: System for purification of polluted water. Washingt. DC.

93. Singh V, M.A.K., 2009. Toxicity analysis and public health aspects of municipal landfill leachate: a case study of Okhla landfill, Delhi Vijaya Singh. Indian Inst. Technol. Delhi; Toxicity Anal. Public Heal. Asp. Munic., Delhi.

94. Sklarz, M.Y., Gross, A., Yakirevich, A., Soares, M.I.M., 2009. A recirculating vertical flow constructed wetland for the treatment of domestic wastewater. Desalination. https://doi.org/10.1016/j. desal.2008.09.002

95. Sohsalam, P., Sirianuntapiboon, S., 2008. Feasibility of using constructed wetland treatment for molasses wastewater treatment. Bioresour. Technol. https://doi.org/10.1016/j.biortech.2007.10.033

96. Stefanakis, A.I., 2020. Constructed wetlands for sustainable wastewater treatment in hot and arid climates: Opportunities, challenges and case studies in the Middle East. Water (Switzerland). https:// doi.org/10.3390/W12061665

97. Stefanakis, A.I., 2015. Constructed wetlands: Description and benefits of an eco-tech water treatment system, in: Impact of Water Pollution on Human Health and Environmental Sustainability. https:// doi.org/10.4018/978-1-4666-9559-7.ch012

98. Stefanakis, A.I., Akratos, C.S., Tsihrintzis, V.A., 2011. Effect of wastewater step-feeding on removal efficiency of pilot-scale horizontal subsurface flow constructed wetlands. Ecol. Eng. https://doi. org/10.1016/j.ecoleng.2010.11.006

99. Stottmeister, U., Wießner, A., Kuschk, P., Kappelmeyer, U., Kästner, M., Bederski, O., Müller, R.A., Moormann, H., 2003. Effects of plants and microorganisms in constructed wetlands for wastewater treatment, in: Biotechnology Advances. https://doi. org/10.1016/j.biotechadv.2003.08.010

100. Tanaka, N., Ng, W.J., Jinadasa, K.B.S.N., 2011. Wetlands for tropical applications: Wastewater treatment by constructed wetlands, Wetlands for Tropical Applications: Wastewater Treatment by Constructed Wetlands. https://doi.org/10.1142/P59

101. Tews, J., Brose, U., Grimm, V., Tielbörger, K., Wichmann, M.C., Schwager, M., Jeltsch, F., 2004. Animal species diversity driven by habitat heterogeneity/diversity: The importance of keystone structures. J. Biogeogr. https://doi. org/10.1046/j.0305-0270.2003.00994.x

102. Thomas, D.J.L., Tyrrel, S.F., Smith, R., Farrow, S., 2009. Bioassays for the evaluation of landfill leachate toxicity. J. Toxicol. Environ. Heal. - Part B Crit. Rev. https://doi.org/10.1080/10937400802545292

103. Touchette, B.W., Iannacone, L.R., Turner, G.E., Frank, A.R., 2007. Drought tolerance versus drought avoidance: A comparison of plant-water relations in herbaceous wetland plants subjected to water withdrawal and repletion. Wetlands. https://doi.org/10.1672/ 0277-5212(2007)27[656:DTVDAA]2.0.CO;2

104. Umi Raihana, A.R., Sharifah Norkhadijah, S.I., Emilia, Z.A., Praveena, S.M., 2014. Landfill leachate toxicity analysis with Orechromis mossambicus (Mozambique tilapia): a review. Int. J. Sci. Basic Appl. Res. 18, 198-216.

105. Van Doremalen, N., Bushmaker, T., Morris, D.H., Holbrook, M.G., Gamble, A., Williamson, B.N., Tamin, A., Harcourt, J.L., Thornburg, N.J., Gerber, S.I., Lloyd-Smith, J.O., De Wit, E., Munster, V.J., 2020. Aerosol and surface stability of SARSCoV-2 as compared with SARS-CoV-1. N. Engl. J. Med. https://doi.org/10.1056/NEJMc2004973

106. Vymazal, J., 2013. Emergent plants used in free water surface constructed wetlands: A review. Ecol. Eng. https://doi.org/10.1016/j.ecoleng.2013.06.023

107. Vymazal, J., 2011a. Plants used in constructed wetlands with horizontal subsurface flow: A review. Hydrobiologia. https://doi.org/10.1007/ s10750-011-0738-9

108. Vymazal, J., 2011b. Constructed wetlands for wastewater treatment: Five decades of experience. Environ. Sci. Technol. https://doi.org/10.1021/es101403q

109. Vymazal, J., 2007. Removal of nutrients in various types of constructed wetlands. Sci. Total Environ. https://doi.org/10.1016/j.scitotenv.2006.09.014

110. Vymazal, J., 2005. Horizontal sub-surface flow and hybrid constructed wetlands systems for wastewater treatment, in: Ecological Engineering. https:// doi.org/10.1016/j.ecoleng.2005.07.010

111. Vymazal, J., Kröpfelová, L., 2009. Removal of organics in constructed wetlands with horizontal sub-surface flow: A review of the field experience. Sci. Total Environ. https://doi.org/10.1016/j. scitotenv.2008.08.032

112. Walton, W.E., 2019. Constructed wetlands still produce mosquitoes. Proc. Pap. Mosq. Vector Control Assoc. Calif. Mon. 87, 1.

113. Wang, J., Chen, Y., Huang, J., Qiao, W., Zhang, W., Yang, Q., 2009. Comparison of genetic diversity between in-situ conserved and non-conserved Oryza rufipogon populations in China. Acta Agron. Sin. 35, 1474-1482.

114. Wang, X., Sun, C., Gao, S., Wang, L., Shuokui, H., 2001. Validation of germination rate and root 
elongation as indicator to assess phytotoxicity with Cucumis sativus. Chemosphere. https://doi. org/10.1016/S0045-6535(00)00520-8

115. Wetzel, P.R., Van Der Valk, A.G., 1998. Effects of nutrient and soil moisture on competition between Carex stricta, Phalaris arundinacea, and Typha latifolia. Plant Ecol. https://doi. org/10.1023/A:1009751703827

116. Wojciechowska, E., Gajewska, M., 2013. Partitioning of heavy metals in sub-surface flowtreatment wetlands receiving high-strength wastewater. Water Sci. Technol. https://doi.org/10.2166/wst.2013.283

117. Wong, M.H., 1989. Toxicity test of landfill leachate using Sarotherodon mossambicus (freshwater fish). Ecotoxicol. Environ. Saf. https://doi. org/10.1016/0147-6513(89)90033-X

118. Wu, F.Y., Chung, A.K.C., Tam, N.F.Y., Wong, M.H., 2012. Root exudates of wetland plants influenced by nutrient status and types of plant cultivation. Int. J. Phytoremediation. https://doi.org/ 10.1080/15226514.2011.604691

119. Wu, H., Zhang, J., Li, C., Fan, J., Zou, Y., $2013 a$. Mass balance study on phosphorus removal in constructed wetland microcosms treating polluted river water. Clean - Soil, Air, Water. https://doi. org/10.1002/clen.201200408

120. Wu, H., Zhang, J., Wei, R., Liang, S., Li, C., Xie, H., 2013b. Nitrogen transformations and balance in constructed wetlands for slightly polluted river water treatment using different macrophytes. Environ. Sci. Pollut. Res. https://doi.org/10.1007/ s11356-012-0996-8

121. Wu, H., Zhang, Jian, Li, P., Zhang, Jinyong, Xie, H., Zhang, B., 2011. Nutrient removal in constructed microcosm wetlands for treating polluted river water in northern China. Ecol. Eng. https://doi. org/10.1016/j.ecoleng.2010.11.020

122. Xiong, Y., Peng, S., Luo, Y., Xu, J., Yang, S., 2015. A paddy eco-ditch and wetland system to reduce non-point source pollution from rice-based production system while maintaining water use efficiency. Environ. Sci. Pollut. Res. https://doi. org/10.1007/s11356-014-3697-7

123. Yalçuk, A., Ugurlu, A., 2020. Treatment of landfill leachate with laboratory scale vertical flow constructed wetlands: plant growth modeling. Int. J. Phytoremediation 22, 157-166. https://doi.org/10 .1080/15226514.2019.1652562

124. Yan, H., Cousins, I.T., Zhang, C., Zhou, Q., 2015. Perfluoroalkyl acids in municipal landfill leachates from China: Occurrence, fate during leachate treatment and potential impact on groundwater. Sci. Total Environ. https://doi.org/10.1016/j. scitotenv.2015.03.111

125. Yari, S., Moshammer, H., Fallah Asadi, A., Mosavi jarrahi, A., 2020. Side effects of using disinfectants to fight COVID-19. Asian Pacific J. Environ. Cancer. https://doi.org/10.31557/apjec.2020.3.1.9-13
126. Yeh, T.Y., Chou, C.C., Pan, C.T., 2009. Heavy metal removal within pilot-scale constructed wetlands receiving river water contaminated by confined swine operations. Desalination. https://doi. org/10.1016/j.desal.2008.11.025

127. Zahui, F.M., Pétémanagnanouattara, J., Messou, A., Coulibaly, L., 2018. Original Research Article Original Research Article Open Access Nutrient Removal and Balance in Vertical-Flow Constructed Wetlands Planted With Different Forage Macrophytes for Domestic Wastewater Treatment 08, 21046-21055.

128. Žaltauskaite, J., Čypaite, A., 2008. Assessment of landfill leachate toxicity using higher plants. Environ. Res. Eng. Manag. 46.

129. Zanelato, R., Bonatto, I. da C., Restrepo, J.J.B., Puerari, R.C., Matias, W.G., de Castilhos Junior, A.B., 2019. Toxicity of leachates from pilot reactors simulating a landfill with different concentrations of AgNP. Eng. Sanit. e Ambient. https://doi. org/10.1590/s1413-4152201920180239

130. Zhang, C.B., Wang, J., Liu, W.L., Zhu, S.X., Ge, H.L., Chang, S.X., Chang, J., Ge, Y., 2010. Effects of plant diversity on microbial biomass and community metabolic profiles in a full-scale constructed wetland. Ecol. Eng. https://doi.org/10.1016/j.ecoleng.2009.09.010

131. Zhang, Z., Rengel, Z., Meney, K., 2007a. Nutrient removal from simulated wastewater using Canna indica and Schoenoplectus validus in mono- and mixed-culture in wetland microcosms. Water. Air. Soil Pollut. https://doi.org/10.1007/ s11270-007-9359-3

132. Zhang, Z., Rengel, Z., Meney, K., 2007b. Growth and resource allocation of Canna indica and Schoenoplectus validus as affected by interspecific competition and nutrient availability. Hydrobiologia. https://doi.org/10.1007/s10750-007-0733-3

133. Zheng, Y., Wang, X., Dzakpasu, M., Zhao, Y., Ngo, H.H., Guo, W., Ge, Y., Xiong, J., 2016. Effects of interspecific competition on the growth of macrophytes and nutrient removal in constructed wetlands: A comparative assessment of free water surface and horizontal subsurface flow systems. Bioresour. Technol. https://doi.org/10.1016/j.biortech.2016.02.008

134. Zhu, H., Zhou, Q.W., Yan, B.X., Liang, Y.X., Yu, X.F., Gerchman, Y., Cheng, X.W., 2018. Influence of vegetation type and temperature on the performance of constructed wetlands for nutrient removal. Water Sci. Technol. https://doi.org/10.2166/wst.2017.556

135. Zurita, F., de Anda, J., Belmont, M.A., 2006. Performance of laboratory-scale wetlands planted with tropical ornamental plants to treat domestic wastewater. Water Qual. Res. J. Canada. https:// doi.org/10.2166/wqrj.2006.044

136. Zurita, F., White, J.R., 2014. Comparative study of three two-Stage hybrid ecological wastewater treatment systems for producing high nutrient, reclaimed water for irrigation reuse in developing countries. Water (Switzerland). https://doi. org/10.3390/w6020213 